\title{
International Journal of Applied Information Technology
}

http://journals.telkomuniversity.ac.id/ijait

\section{Proposed IT Governance at Hospital Based on COBIT 5 Framework}

\author{
Heru Nugroho \\ Diploma of Informatics Management, School of Applied Science, Telkom University, Indonesia
}

\section{A R T I C LE INFO}

Received June 7, 2017

Revised July 24, 2017

Accepted August 9, 2017

Available online August 14, 2017

Keywords

IT Governance, Hospital; COBIT 5, Enablers

\begin{abstract}
A B S T R A C T
Information Technology (IT) Governance in Hospitals describe how to create an IT governance process that increases the number of IT projects that support the strategy of a hospital and are completed on-time and on- budget. Good IT governance aligns decisions about the use of IT with desired behaviors and organizational objectives. The existence of good IT governance at Hospitals is expected to provide improvement on quality, functionality, and ease of use of the service. Enablers in COBIT 5 framework can be applied in practical situations and can be used to implement effective and efficient information governance and data management of IT governance for Hospital. In this paper, we propose IT governance in Hospital base on COBIT 5 framework. In the preparation of the proposed IT governance model, the enablers that exist in COBIT 5 framework is used as a determining factor. For performing the optimization of IT services to achieve the normal vision and mission uses base on a model of IT governance for a hospital
\end{abstract}

\footnotetext{
* Corresponding author at:

Diploma of Informatics Management, Telkom University,

Jl. Telekomunikasi No. 1, Terusan Buah Batu, Bandung, 40257

Indonesia.

E-mail address: heru@tass.telkomuniversity.ac.id

ORCID ID:

Author: 0000-0002-7460-7687
} 


\section{Introduction}

The success of implementing effective governance in an organization associated with the right pattern or fit for the organization so that they can be a complement or supplement of organization's strategic focus. Information technology (IT) governance is not a static concept but rather processes inherent in the organization [1]. IT performance correlated with organizational performance, which confirms the strategic role that IT plays in organizations. The relational mechanisms between IT and other organizational units are, in the IT governance context, the determining factors for IT performance [2].

The development of information technology (IT) will certainly affect how hospital management in building better governance in a transparent, structured and accountable so it can increase profitability and enablement resources optimally. The IT utilization for the hospital was a factor that could help the activity of service, sales, and marketing hospital [3]. The service functions that are built into the blueprint of IT which contains the IT governance has provided a new perspective in the effort towards good IT Governance [4]. Improved quality of information services will provide a strong influence towards presenting information so that it is aligned with the business processes that occur to achieve the vision, mission, and goals of the hospital [5]. Business processes that occur need to be aligned with the purpose of the management of hospitals which have been defined in the form of it governance policies. The existence of the IT governance at both Hospitals are expected to [6]:

1. Provide improved on quality, functionality, and ease of use of the service;

2. Speed up the process; and

3. On an ongoing basis can improve the level of service against all expectations through the fulfillment of the relatively low cost of realization and efficient use of resources.

Along with the growth of the hospital that one of the patients is some charge indicators will grow naturally have an impact on hospital revenue generated each year. Therefore, the support of qualified information technology into something that is critical to improving the services provided by the hospital. However, the application of IT in a company is not always aligned with the strategy and objectives of the enterprise. For it to be done an analysis of infrastructure and existing its management to be always ensured the conformity of existing infrastructure and management with the purpose of the company [7]. For the application of IT in the hospital can generate value expectations, aligned with objectives, and reduces the risk of the business, it needs to be improved IT governance is implemented on an ongoing basis.

COBIT 5 frameworks can be used by an organization in implementing IT governance to support the achievement of the objectives. By selecting the processes by the aims of the Organization, the frameworks COBIT 5 provides a guide how should those processes are planned, build, run, and evaluated. In this paper, will propose IT governance at the hospital based on COBIT 5 Framework.

\section{Research Methodology}

Our research follows the Design Science Research Methodology (DSRM). There are six steps in the DSRM process, problem identification, and motivation, the definition of the objectives for a solution, design and development, 
demonstration, evaluation, and communication (Figure 1). In this study, we use the step until design and development.



Figure 1 Design Science Research Methodology [8]

1. Problem Definitions

The problem that focuses in this paper is how to give a guide for Hospital for implementing IT Governance.

2. Defining Solution

The solution is defining with a literature review related to papers or research related IT governance in Hospital. Solutions build the solution are developed based on the author's experiences while working on projects related to IT governance.

3. Design and Model Development Demonstrations

Design and model IT Governance for the hospital is development base on COBIT 5 framework. In this step, describe how IT governance implemented in Hospital.

\section{Related Work}

Strong leadership becomes a success factor of IT governance in the organization. In addition, another important factor is the organizational ability to manage change. Good IT governance must be able to align IT usage decisions with desired organizational behavior and objectives. IT implementation requires substantial investment so that IT should focus on organizational strategy priorities. The value of IT depends on better technology. Related Governance, top level management must make decisions about the transparency of IT such as standardization versus innovation [9].

Designing and implementing an effective IT governance process takes time and effort, but it is necessary to keep pace with regulatory compliance. Currently, IT Governance in Hospitals and Health Systems is a must. Good IT governance will support the number of IT projects that support the strategy and can clarify time and budget. Without a governance structure, IT in many hospitals and health systems are useless, the budget IT is not consistent with the results obtained and in the end many different systems that are not functioning properly [10]. Hospitals have clearly identified Information Technology Governance domains factors as possible threats to the success of an IT governance framework [11]. 


\section{The Important of IT Governance For Organization}

A control framework for IT governance defines the reasons IT governance is needed, the stakeholders and what it needs to accomplish. IT Governance is essential for the organization because [12]:

1. Management expects a heightened understanding of the way IT is operated and the likelihood of its being leveraged successfully for competitive advantage.

2. Successful enterprises understand the risks and exploit the benefits of IT and find ways to deal with aligning IT strategy with the business strategy, Cascading IT strategy and goals down into the enterprise, and Measuring IT performance.

3. The organization cannot deliver effectively against these business and governance requirements without adopting and implementing a governance and control framework for IT to define the management control objectives to be considered.

4. Governance and control frameworks are becoming a part of IT management good practice and are an enabler for establishing IT governance and complying with continually increasing regulatory requirements.

5. Business managers and boards demanding a better return on IT investments, i.e., that IT delivers what the business needs to enhance stakeholder value.

\section{Proposed IT Governance at Hospital Base on COBIT 5 Framework}

ISO 38500 framework as a basis for developing a proposal for a model of IT Governance Model at Hospital able to translate the vision and mission of the company becomes operational measures required with enabler in COBIT 5 framework made a guide in the process of Plan, Built, Run, and Monitor as an IT Governance process (can be seen in Figure 2)

In Figure 2, Pressure and business needs in the management of the hospital will serve as input for the evaluation of the management of the hospital. About the IT governance, the pressure in the hospital is providing service excellent for the community. Business needs related to good corporate governance and good clinical governance. The pressures of business and business needs that will be part of the evaluation of the management in establishing the plan of strategy for the hospital in the context of the achievement of the vision and mission. Under the laws of the Republic of Indonesia Number 44 In 2009 About Hospital, the goals of the establishment of the hospital are:

1. Organization of health services treatment and recovery by service standards the hospital;

2. Maintenance and upgrading individual health through plenary health services second and third level corresponding medical needs;

3. Organization of the education and training of human resources to increase skills in administering health services; and

4. Organization of research and development, as well as filtering technology in the health field order, increased health services with attention to ethics in science fields health. 


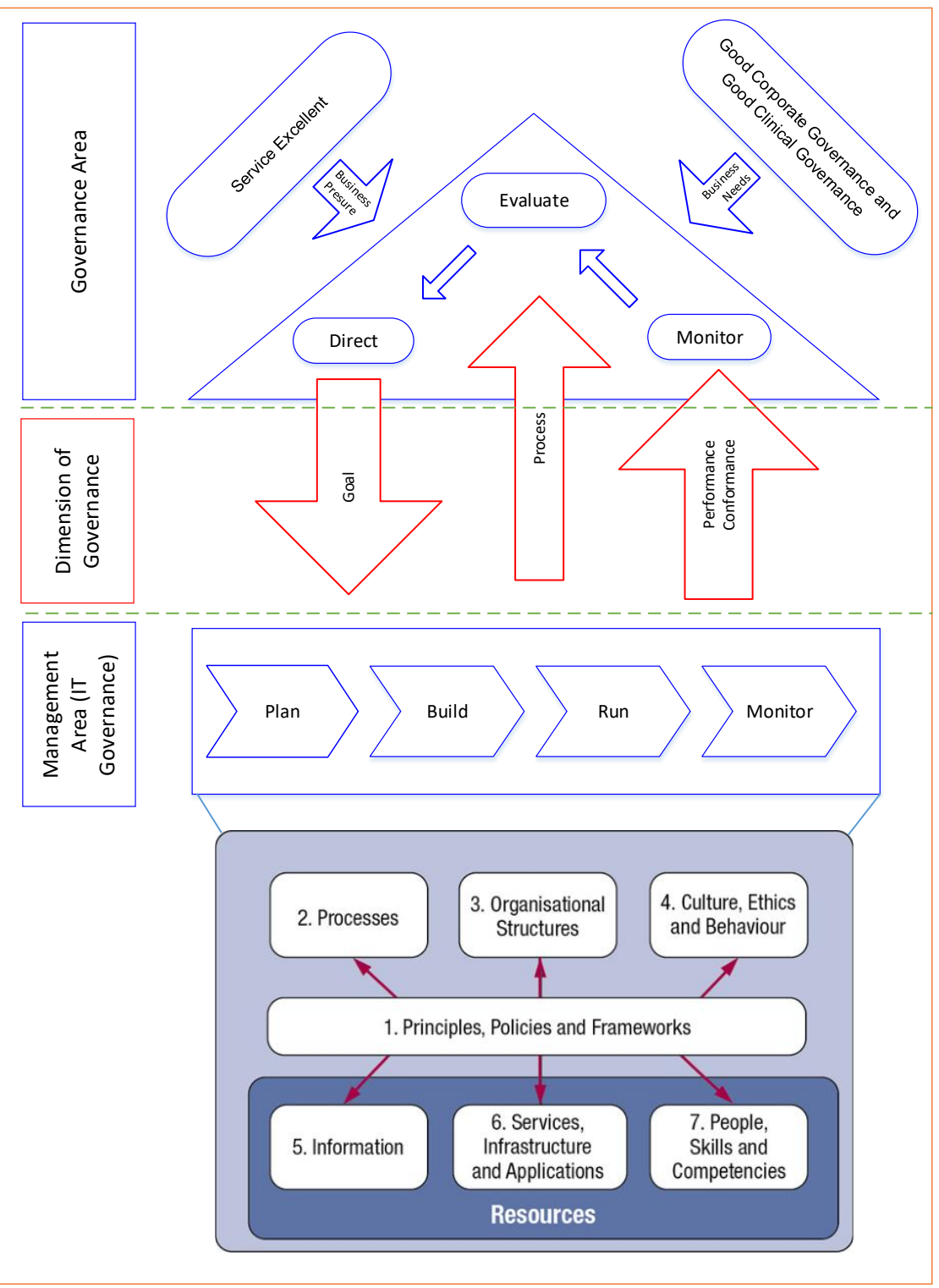

Figure 2 IT Governance Model at Hospital

Management will translate the goal or objective into activity i.e. plan, build, run, and monitoring monitor. On this stage, the function of IT governance is implemented by sorting out the IT processes that are in line with the achievement of the vision and mission of the hospital. IT governance activity will be influenced by the enabler. Enablers are factors that, individually or collectively, influence whether something will work that inline with the goal of the organization. In this case, governance and management of enterprise IT. The goals cascade drives enablers, i.e., higher-level IT-related goals define what the different enablers should achieve. The COBIT 5 framework is described seven categories of enablers [13].

1. Principles, policies, and frameworks are the vehicles to translate the desired behavior into practical guidance for day-to-day management at Hospital.

2. Processes describe a Hospital set of practices and activities to achieve the objectives and produce a set of outputs to support and achieving overall ITrelated goals.

3. Organizational structures are the key decision-making entities in a Hospital. 
4. Culture, ethics, and behavior of individuals and the hospital as a success factor in governance and management activities.

5. Information is pervasive throughout any organization and includes all information produced and used by the hospital. Information is required for keeping the organization running and well governed, but at the operational level, information is very often the key product of the hospital itself.

6. Services, infrastructure, and applications include the infrastructure, technology, and applications that provide the hospital with information technology processing and services.

7. People, skills, and competencies are linked to people and are required for successful completion of all activities and for making correct decisions and taking corrective actions in a hospital.

COBIT 5 includes a process reference model, which defines and describes in detail several governances and management processes. It represents all of the processes normally found in Hospital relating to IT activities, providing a common reference model understandable to operational IT and business managers. Based on previous research that refers to the IT governance in the hospital, some IT process in COBIT 5 Process Reference Model is relevant and can be used in implementing IT governance in Hospital are as follows:

1. Align, Plan and Organize

- APO01 Manage the IT Management Framework

- APO02 Manage Strategy

- APO03 Manage Enterprise Architecture

- APO06 Manage Budget and Costs

- APO07 Manage Human Resources

- APO09 Manage Service Agreements

2. Build, Acquire and Implement

- BAI02 Manage Requirements Definition

- BAI03 Manage Solutions Identification and Build

- BAI09 Manage Assets

3. Deliver, Service, and Support

- DSS01 Manage Operations

- DSS02 Manage Service Requests and Incidents

- DSS03 Manage Problems

- DSS06 Manage Business Process Controls

4. Monitor, Evaluate and Assess

- MEA01 Monitor, Evaluate and Assess Performance and Conformance

- MEA02 Monitor, Evaluate and Assess the System for Internal Control

\section{Conclusion}

The existence of good IT governance at Hospitals is expected to Provide improved on quality, functionality, and ease of use of the service. Enablers in COBIT 5 framework can be applied in practical situations and can be used to implement effective and efficient information governance and data management of IT governance for Hospital. In this paper, we present proposed IT governance in Hospital base on COBIT 5 framework. The enablers that exist in COBIT 5 framework will be used as a determining factor in the preparation of the proposed 
model of IT governance. The results contribute to give a model of IT governance for a hospital that can be used by hospitals in performing the optimization of IT services to achieve the normal vision and mission.

\section{Bibliography}

[1] Nugroho, H., 2014. Conceptual model of IT governance for higher education based on COBIT 5 framework. Journal of Theoretical and Applied Information Technology, Vol. 60 No.2, pp.216-221

[2] Adriano et all, 2015. IT governance in the public sector: a conceptual model. Inf Syst Front DOI Springer Science+Business Media New York.

[3] Hartono, 2010. Rancang Bangun Electronic Customer Relationship Management (ECRM) Sebagai Sistem Informasi Layanan Pelanggan Pada Rumah Sakit Mata "Dr. Yap" Yogyakarta, Skripsi. STMIK Amikom Yogyakarta.

[4] Saptadi, Tri. 2014. Model Penyusunan Blue Print Information Technology Governance di Rumah Sakit. Prosiding KNSI STMIK Dipanegara. Makassar. Edisi 27 Pebruari 2014, ISSN: 2355-1941.

[5] Daryatno, Budi, 2007. Perancangan Cetak Biru Teknologi Informasi, Jurnal Algoritma, Volume 3 Nomor 3. Oktober, STMIK MDP Palembang.

[6] N. Tri Suswanto Saptad, Hans Christian Marwi., 2014. Hospital Function Services Model by Data Warehouse. JTRISTE, Vol.1, No.2, Oktober 2014, pp. 16 - 25 ISSN: 2355-3677.

[7] Surendrro, K., 2009. Implementasi Tatakelola Teknologi Informasi. Penerbit Informatika Bandung.

[8] Ken Peffers, et all., 2007. A Design Science Research Methodology for Information Systems Research. Journal of Management Information Systems, Volume 24 Issue 3, pp: 45-78.

[9] Wiedower, James S., 2016. Information Technology Governance: Vital to Healthcare Systems. Scholar Archive. Paper 3753.

[10] Kropf \& Scalzi, 2013. IT Governance in Hospitals and Health Systems.Journal of Healthcare Information Management, HIMSS, Spring 2013

[11] M. Shahi, F. Sadoughi, and M. Ahmadi, "Information Technology Governance Domains in Hospitals: A Case Study in Iran," Glob. J. Health Sci., vol. 7, no. 3, 2015.

[12] IT Governance Institute, 2007. COBIT 4.1 ISBN 1-933284-72-2 Printed in the United States of America

[13] Information System Audit Control Association. 2012. COBIT® 5 Framework. IL, USA: ISACA 